\title{
An oxygen isotope test for the origin of Archean mantle roots
}

\author{
M.E. Regier ${ }^{1 *}$, A. Mišković ${ }^{2,3}$, R.B. Ickert ${ }^{1,4}$, D.G. Pearson ${ }^{1}$, \\ T. Stachel ${ }^{1}$, R.A. Stern ${ }^{1}$, M. Kopylova ${ }^{5}$
}

Abstract

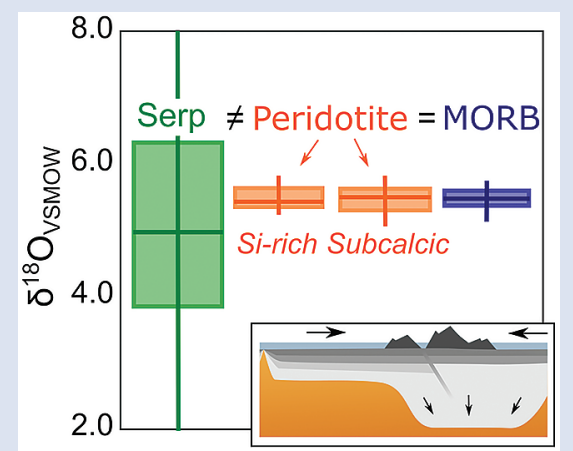

The origin of the peridotites that form cratonic mantle roots is a central issue in understanding the history and survival of Earth's oldest continents. A longstanding hypothesis holds that the unusual bulk compositions of some cratonic peridotites stem from their origin as subducted oceanic serpentinite, dehydrated during subduction to form rigid buoyant keels (Schulze, 1986; Canil and Lee, 2009). We present oxygen isotope data from 93 mantle peridotites from five different Archean cratons to evaluate their possible origin as serpentinites. Cratonic mantle peridotite shows remarkably uniform $\delta^{18} \mathrm{O}$ values, identical to modern MORB-source mantle, that do not vary with bulk rock Si-enrichment or Ca-depletion. These data clearly conflict with any model for cratonic lithosphere that invokes serpentinite as a protolith for cratonic peridotite, and place additional constraints on cratonic mantle origins. We posit that the uniform $\delta^{18} \mathrm{O}$ was produced by sub-arc and/or MOR depletion processes and that the Si-enriched nature of some samples is unlikely to be related to slab melt infiltration. Instead, we suggest a peridotitic source of Si-enrichment, derived from ascending mantle melts, or a water-fluxed depleted mantle. These variably Si-enriched, cratonic mantle protoliths were then collisionally compressed into the thick cratonic roots that have protected Earth's oldest continental crust for over 2.5 Gyr.

Received 30 July 2018 | Accepted 6 November 2018 | Published 7 December 2018

\section{Models of Craton Formation}

An essential element to the study of the growth and longevity of Earth's continental crust is the origin of the chemically buoyant and rigid lithospheric mantle that underpins ancient continental cratons. The vast majority of geochemical evidence for the origin of cratonic peridotites supports initial melt extraction at pressures $\leq 5 \mathrm{GPa}$, with most melting occurring in the spinel stability field. This depletion in a shallow, spinelbearing environment is indicated by low concentrations of mildly incompatible elements and the $\mathrm{Cr}$-rich nature of garnet in cratonic peridotites (Stachel et al., 1998; Canil, 2004; Brey and Shu, 2018). If a moderate to low pressure origin is accepted, then two end member models remain. The first model (Fig. 1a) invokes the successive imbrication of subducted oceanic lithosphere (e.g., Helmstaedt and Schulze, 1989; Pearson and Wittig, 2008). The second model - collisional compression via pure shear (Fig. 1b) - proposes that depleted mantle protoliths from Neoarchean sub-arc settings and/or in hot spreading centres are tectonically amalgamated, compressed, and gravitationally thickened during cooling (Jordan, 1978; Lee et al., 2011; Wang et al., 2016). The serpentinite-like major element signatures of some peridotites (Si-enriched bulk rock and subcalcic garnets) have been used to support the imbrication of hydrated oceanic lithosphere (Schulze, 1986; Canil and Lee, 2009). However, these cratonic peridotites have not been systematically tested for the distinctive oxygen isotopic ratios that are characteristic of serpentinites. Here, we search for these distinctive isotopic signatures in mantle-derived cratonic xenoliths.

\section{Approach and Results}

To characterise the oxygen isotopic composition of cratonic mantle peridotites we present ion microprobe analyses (Supplementary Information) of olivines from coarse, "low-temperature" peridotite xenoliths (Table S-1), thought to represent the bulk of the cratonic lithospheric mantle. The sample suite is derived from the Slave, Rae, North Atlantic, Kaapvaal, and Siberian Archean cratons, and excludes cratonic peridotites that were modified after emplacement by high temperature deformation and melt metasomatism. We also report precise laser fluorination and ion probe measurements on cratonic mantle orthopyroxene (Opx) as well as olivine from forearc peridotites.

\footnotetext{
1. Canadian Centre for Isotopic Microanalysis, Department of Earth and Atmospheric Sciences, University of Alberta, Edmonton AB, Canada

NWT Geological Survey, Yellowknife, NT, Canada

GeoTarget Solutions Inc., Burnaby, BC, Canada

Scottish Universities Environmental Research Centre, East Kilbride, Scotland

Department of Earth, Ocean, and Atmospheric Sciences, Vancouver, BC, Canada

Corresponding author (email: margoregier@gmail.com)
} 
a

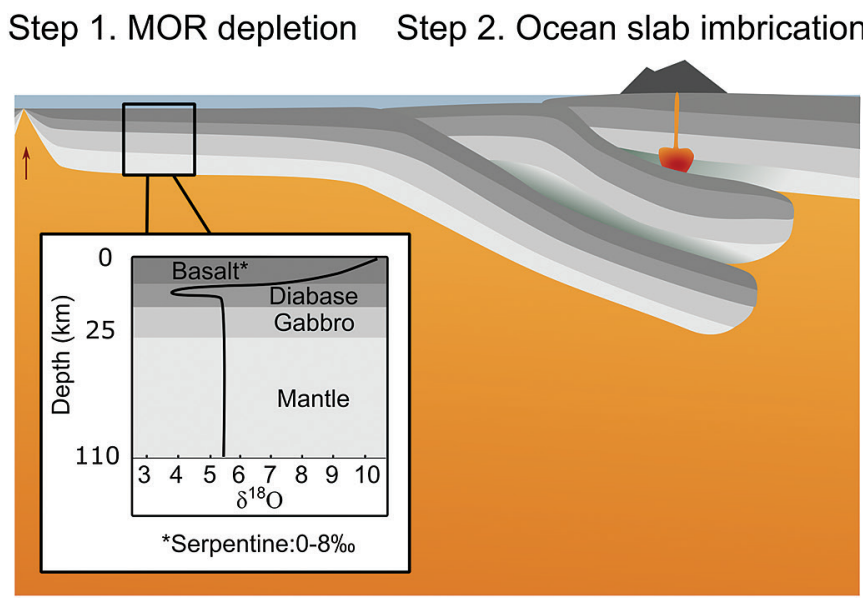

b

Step 1. MOR and/or sub-arc depletion

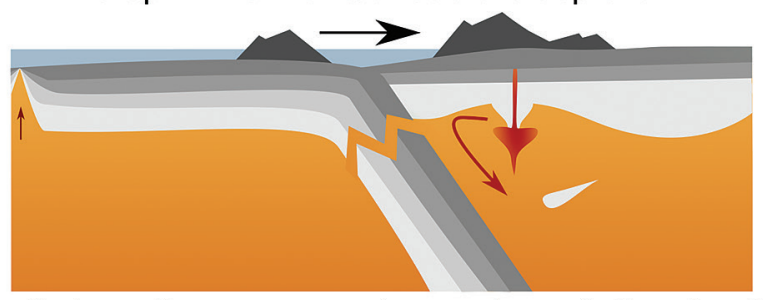

Step 2. Accretion, compression, and gravitational settling

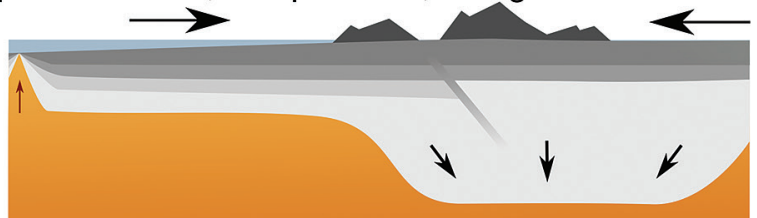

Figure 1 Popular models of cratonic mantle formation. (a) Imbrication of MOR sequences to form a thick lithosphere. An estimated oxygen isotope profile through Neoarchean oceanic lithosphere is inset. (b) Depleted cratonic mantle protoliths produced at MOR and in sub-arc environments are compressed via pure shear into a thick lithospheric root.
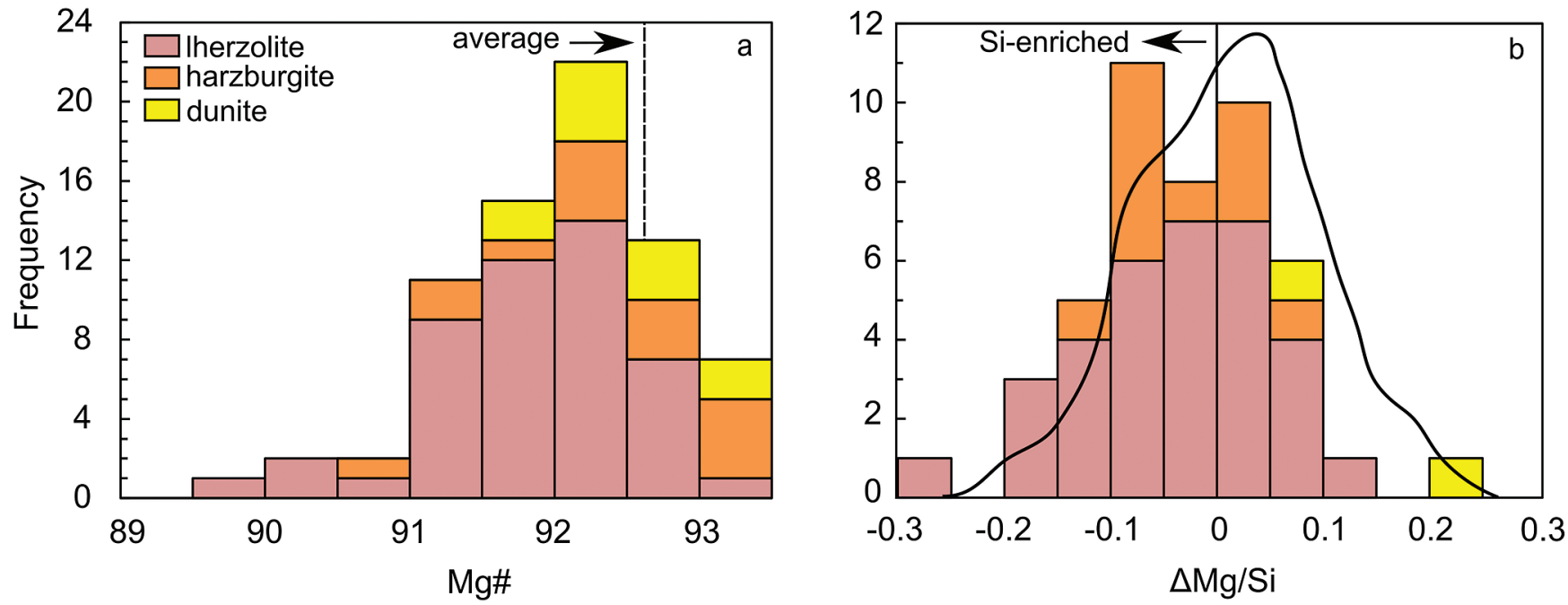

Figure 2 (a) Mg\# histogram of olivines in this study. Mg\#s are both more and less depleted than the worldwide average for olivine in cratonic peridotite, denoted by the dotted line (Pearson and Wittig, 2008). (b) $\Delta \mathrm{Mg} / \mathrm{Si}$ histogram of samples compared to a vertically unscaled probability density function for worldwide cratonic mantle xenoliths from Canil and Lee (2009). Negative $\Delta \mathrm{Mg} / \mathrm{Si}$ designates Si-enriched lithologies.

Our samples span both sides of the average cratonic mantle olivine $\mathrm{Mg} \#$ (molar $\mathrm{Mg} / \mathrm{Mg}+\mathrm{Fe}$ ) of 92.6 (Fig. 2a). A subset of our samples are Si-enriched, manifested as high bulk rock $\mathrm{SiO}_{2}$ and elevated modal Opx contents. We adopt the $\Delta \mathrm{Mg} / \mathrm{Si}$ parameter of Canil and Lee (2009) to quantify Si-enrichment (Fig. 2b), where negative $\Delta \mathrm{Mg} / \mathrm{Si}$ denotes Si-enriched, or a lower $\mathrm{Mg} / \mathrm{Si}$ and $\mathrm{Al} / \mathrm{Si}$ than can be produced by experimental partial melts of peridotite.

Our measurements reveal that cratonic mantle olivines are normally distributed (Shapiro-Wilk $\mathrm{W}=0.99, \mathrm{p}=0.52$ ) over an extremely restricted $\delta^{18} \mathrm{O}$ range of +5.01 to $+5.53 \%$, with a mean of $5.26 \pm 0.22 \%$ o $(2 \sigma)$. There are no statistically significant deviations in $\delta^{18} \mathrm{O}$ with chemical proxies (Fig. S-1). Additionally, cratonic mantle Opx from variably Si-enriched xenoliths (Table S-2; mean $\delta^{18} \mathrm{O}$ of $5.74 \pm 0.27 \%$ ) are in isotopic equilibrium with associated olivine $\left(\alpha_{\text {enstatite-olivine }}\right.$ at $1300{ }^{\circ} \mathrm{C}=\sim 0.5 \%$; Rosenbaum et al., 1994).
In order to determine if there are crustal sources of oxygen in the cratonic mantle, we compare our dataset to the well-defined MORB-source mantle (Fig. S-1). We adjust our olivine $\delta^{18} \mathrm{O}$ to whole rock peridotite values using a fractionation factor that accounts for the ultramafic composition. Oxygen isotope fractionation between an ultramafic peridotitic mantle source and olivine at high mantle temperatures has been estimated at $\sim 0.2 \%$ (Valley et al., 1998), based on a basalt-olivine fractionation of $0.32 \%$ at $1300{ }^{\circ} \mathrm{C}$ (Eiler et al., 2000) and the positive correlation between melt $\mathrm{SiO}_{2}$ and

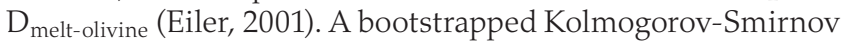
(K-S) statistical evaluation of the MORB dataset and the $0.2 \%$ fractionation-corrected cratonic mantle olivines indicates that they are statistically indistinguishable $(\mathrm{D}=0.11, \mathrm{p}=0.57)$, with both populations having analytical uncertainties equal to or larger than the population variance. In contrast, serpentinised peridotite and cratonic mantle olivine have clearly distinct distributions ( $\mathrm{D}=0.54, \mathrm{p}<0.05$; Fig. 3a). 


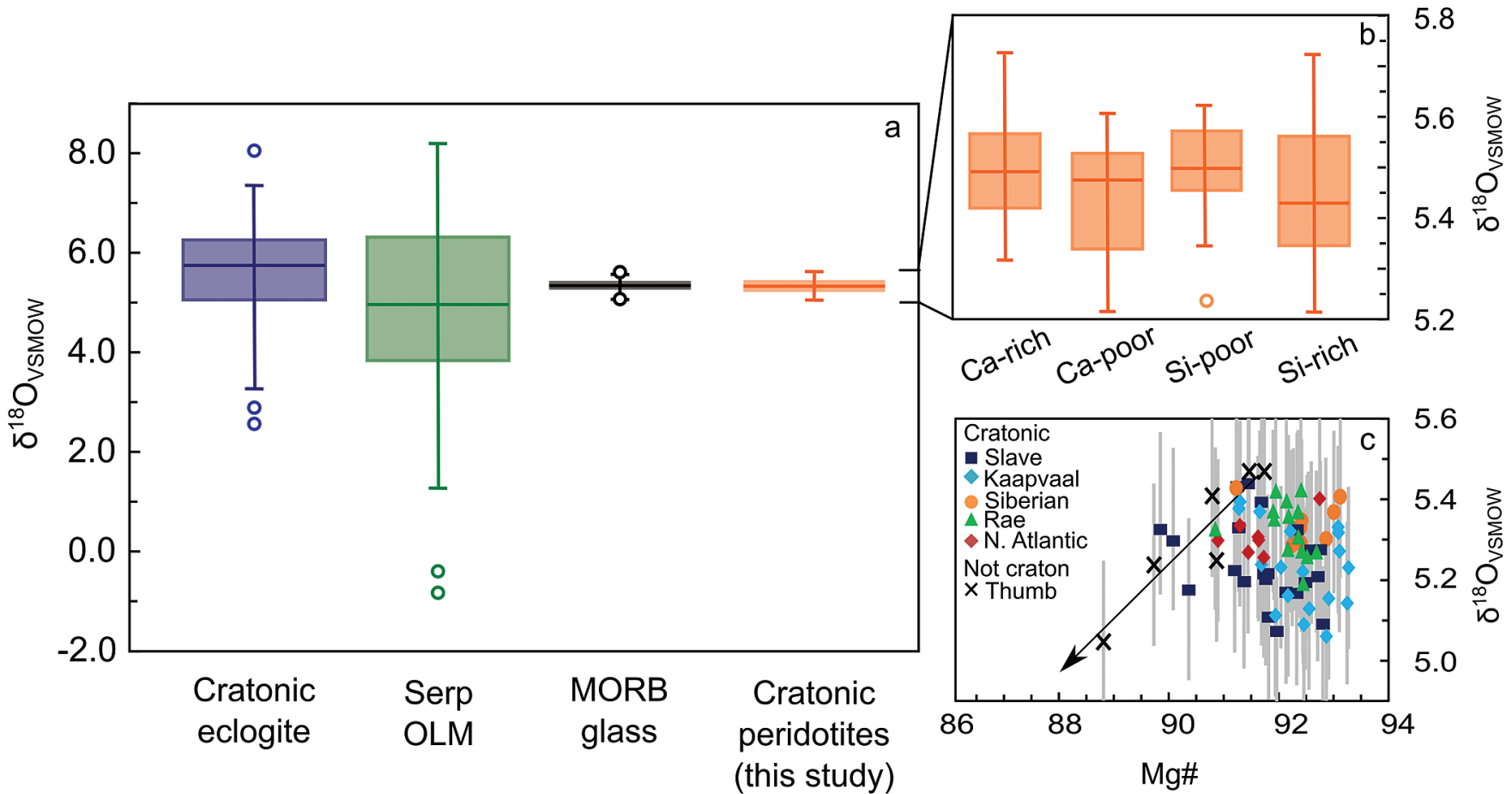

Figure 3 (a) Box-whisker plot of the oxygen isotopic composition of cratonic peridotites, calculated from olivine $\delta^{18} \mathrm{O}$, compared to eclogitic xenoliths, serpentinised oceanic lithospheric mantle (OLM), and MORB glass (Supplementary Information). (b) A box-whisker plot of peridotite $\delta^{18} \mathrm{O}$, divided into statistically insignificant chemical discriminators - Ca-rich (Iherzolitic), Ca-poor (harzburgitic/ dunitic) and Si-enriched $(-\Delta \mathrm{Mg} / \mathrm{Si})$ and depleted lithologies $(+\Delta \mathrm{Mg} / \mathrm{Si})$, demonstrates that there is no variation in the distribution of oxygen isotopes with bulk rock chemistry. (c) Scatter plot of olivine $\delta^{18} \mathrm{O}$ and $\mathrm{Mg \#}$. The lack of correlation in the cratonic mantle suite contrasts to the trendline of The Thumb xenoliths $\left(r^{2}=0.86\right)$.

\section{Implications for Craton Formation}

The striking similarity between oxygen isotope compositions of present day MORB and Archean cratonic peridotites documents the stability of the $\delta^{18} \mathrm{O}$ of Earth's mantle over a 3 billion year interval. Despite this, the diverse $\delta^{18} \mathrm{O}$ values of cratonic eclogite xenoliths demonstrate that $\delta^{18} \mathrm{O}$ heterogeneities in the subcontinental lithospheric mantle can persist even at the metre scale, likely due to the slow diffusion of oxygen. Since hydrothermal alteration, or the serpentinisation of ultramafic rocks, is an effective method of producing highly variable $\delta^{18} \mathrm{O}$ (Wenner and Taylor, 1971), cratonic mantle olivines derived by prograde metamorphism of serpentinite (Canil and Lee, 2009) should retain both serpentinite-like major element chemistry and distinct oxygen isotopic compositions (Fig 3a).

In contrast to the extreme $\delta^{18} \mathrm{O}$ variability of Phanerozoic serpentinite (0 to $+8 \%$; Fig. $3 a)$, cratonic peridotitic olivines are strikingly uniform, even over the full compositional range typical for Archean lithospheric mantle. Olivines co-existing with subcalcic garnets and from $\mathrm{Si}$-enriched peridotites - proposed signatures of a serpentinite origin (Schulze, 1986; Canil and Lee, 2009) - have oxygen isotope compositions that are statistically indistinguishable from normal upper mantle (Fig. 3b). A key piece of evidence previously used in support of the meta-serpentinite hypothesis was a reported correlation between $\delta^{18} \mathrm{O}$ and $\mathrm{Mg} / \mathrm{Si}$ from Colorado Plateau peridotitic xenoliths (Canil and Lee, 2009). We note that this Proterozoic terrane is not under-pinned by an Archean cratonic root, and shows clear evidence of hydrous weakening and thinning ( $\mathrm{Li}$ et al., 2008). Furthermore, our replotting of these data resolves a correlation $\left(r^{2}=0.89\right)$ between $\delta^{18} \mathrm{O}$ and $\mathrm{Mg \#}$ (Fig. 3c). This trend is not consistent with a metaserpentinite origin, as serpentine minerals are commonly higher in $\mathrm{Mg \#}$ than the initial olivine and Opx that they replace (Evans, 2008). Therefore, these samples likely do not represent the products of seafloor alteration processes (Canil and Lee 2009), but may instead be a consequence of the water-rich metasomatism of the Colorado Plateau lithospheric mantle by Si-enriched fluids or melts from the low-angle subducting Farallon Plate at 80-35 $\mathrm{Ma}$ (Li et al., 2008). Finally, as the narrow variance in Archean cratonic mantle peridotite is statistically equivalent to that of MORB, there is no evidence for even small inputs of meta-serpentinite. Hence, meta-serpentinite is an unlikely protolith to the peridotitic root of the Colorado Plateau, and can be rejected as a protolith for Archean cratonic mantle.

While the Colorado Plateau lithosphere is not a good proxy for pristine cratonic mantle, it is a geometric analogue for the Archean slab imbrication model. The low angle subduction that occurred underneath the Colorado Plateau in the Cretaceous to Eocene likely injected slab melts/fluids directly into the overlying lithospheric mantle, offsetting $\delta^{18} \mathrm{O}, \Delta \mathrm{Mg} / \mathrm{Si}$, and $\mathrm{Mg \#}$. The similar geometry required for the Archean slab imbrication model would likely produce the same geochemical traces in cratonic mantle olivine. Since our extensive suite of cratonic mantle olivines does not show "Colorado Plateaulike" systematics (between $\delta^{18} \mathrm{O}$ and metasomatic proxies - $\Delta \mathrm{Mg} / \mathrm{Si}$ or Mg\#; Figs. 3c, S-2), it is unlikely that cratonic mantle thickening occurred by slab imbrication. This lack of a crustal alteration signature would be in line with suggestions of higher pressure melting in plumes, but such a model can be rejected from other considerations that place melt depletion in the spinel stability field (see discussion in Introduction). Instead, we hypothesise that cratonic mantle protoliths were initially depleted at MOR and/or at water fluxed sub-arc mantle wedges, environments that produce material with canonical mantle-like $\delta^{18} \mathrm{O}$ (Table S-3). These protoliths were then thickened, without significant isotopic modification, by pure shear compression to form cratonic mantle roots (Jordan, 1978; McKenzie and Priestley, 2016; Wang et al., 2016). 


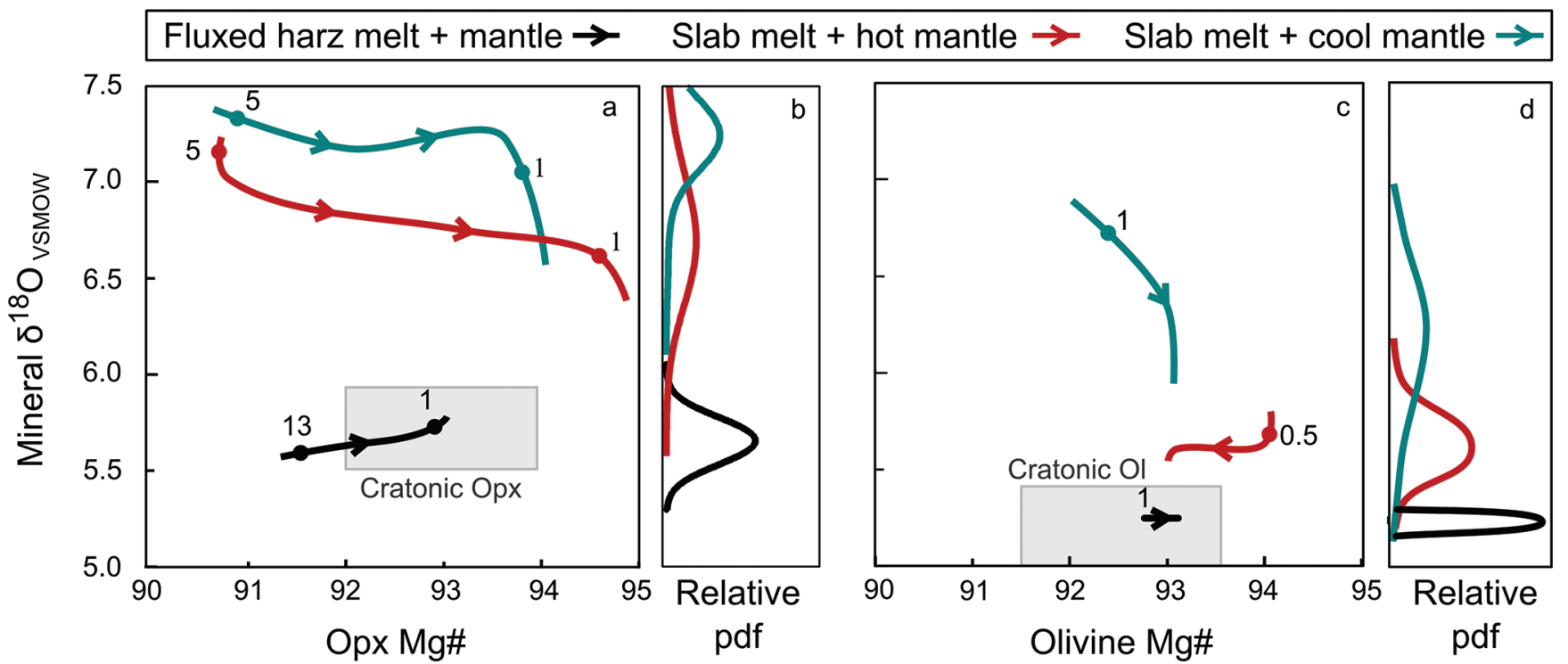

Figure 4 pMELTS modelling of slab melts $\left(\delta^{18} \mathrm{O}\right.$ of $+8 \%$ ) reacting with $900^{\circ} \mathrm{C}$ (blue) and $1500^{\circ} \mathrm{C}$ (red) harzburgite, as well as a waterfluxed harzburgitic (harz) melt $\left(\delta^{18} \mathrm{O}\right.$ of $+5.6 \%$ ) reacting with $1300^{\circ} \mathrm{C}$ harzburgite (black). The major element and isotopic evolution of crystallising Opx (a) and olivine (c) is indicated by smoothed curves. Numbers indicate the slab melt/assimilated peridotite ratio. Typical cratonic mantle Opx and olivine (OI) is outlined in gray fields. Relative Kernel estimations of the probability density function (pdf) for Opx (b) and olivine (d) $\delta^{18} \mathrm{O}$ are included.

While our data is consistent with the construction of cratons by collisional compression of un-altered, depleted peridotite protoliths, we still require a means to enrich these regions heterogeneously in high-Si Opx. Many explanations for cratonic mantle Opx enrichment rely on the infiltration of slab derived melts (e.g., Rudnick, 1994; Kelemen et al., 1998). However, lithosphere that has been thinned by crustal melt infiltration is marked by low $\mathrm{Mg} \#$ and exotic $\delta^{18} \mathrm{O}$ (Wang et al., 2018). Using pMELTS isenthalpic modelling (Ghiorso et al., 2002) of assimilation-fractional crystallisation (AFC) for $100 \mathrm{~g}$ of slab melt at $3 \mathrm{GPa}$, we demonstrate that these melts fractionate garnet at slab melt/assimilated rock ratios of $>5$, followed by Opx (ratios of 1-5), and olivine, once the melt $\mathrm{SiO}_{2}$ drops to $\sim 50$ wt. \% (ratios of $<1$ ). Given the low $\mathrm{MgO}$ and $\mathrm{FeO}$ of experimentally-derived slab melts (Table S-4), high $\mathrm{Mg \#}$ minerals crystallise after minimal assimilation of peridotite. However, producing mantle-like $\delta^{18} \mathrm{O}$ is more difficult (Fig. 4). Mass balance calculations that include fractionation factors (Eiler, 2001) and the compositional and mineralogical outputs of pMELTS (Table S-4), indicate that at the required melt/rock ratios, $\delta^{18} \mathrm{O}$ of Opx and olivine remains higher than mantle. Even melts with modest initial $\delta^{18} \mathrm{O}\left(\right.$ e.g., $\delta^{18} \mathrm{O}$ of +4.0 or $+6.5 \%$ o) cease to crystallise Opx before mantle-like $\delta^{18} \mathrm{O}$ is achieved, due to low melt $\mathrm{SiO}_{2}(<50$ wt. \%). Since the measured $\delta^{18} \mathrm{O}$ of olivine and Opx from Si-enriched cratonic peridotites do not reflect those modelled in slab melt AFC models, we do not support the slab melt infiltration hypothesis for Si-enrichment.

Since Si-enrichment cannot be achieved by eclogite-derived melts and, as previously discussed in the Introduction, does not show evidence for a high pressure origin, we instead suggest two possible low pressure origins: 1) asthenospheric melts that have become Si-enriched due to the assimilation of wall rock pyroxene and fractionation of olivine during ascent (Kelemen et al., 1992), or 2) the infiltration of moderately Si-rich melts $(\sim 56 \mathrm{wt}$. \%) produced from the melting of a depleted harzburgitic mantle fluxed with $~ 2.5$ wt. \% $\mathrm{H}_{2} \mathrm{O}$ from a devolatilising slab (Mitchell and Grove, 2015). When $100 \mathrm{~g}$ of this $+5.6 \%$ harzburgitic melt is input into our AFC model, it crystallises Opx and olivine with cratonic mantle-like Mg\# and $\delta^{18} \mathrm{O}$ (Fig. 4). The proportion of precipitating Opx, and thus, the Si-enrichment of the surrounding rock, is dependent on the evolving melt-rock ratio. The final stage of thickening, via collisional compression of this heterogeneously Si-enriched material, leads to a cratonic mantle root with variable Opx content, but homogeneous oxygen isotopes.

In summary, the $\delta^{18} \mathrm{O}$ homogeneity of a wide range of cratonic mantle peridotites demonstrates that their variably Si-enriched, sometimes subcalcic garnet-bearing nature, cannot have been inherited from protoliths that experienced seafloor serpentinisation (e.g., Schulze, 1986; Canil and Lee, 2009). Instead, these peridotites must have 1) lain at depths in the oceanic lithosphere where circulating water was minimal and 2) avoided extensive metasomatism from imbricating oceanic lithosphere. Based on these observations, we suggest that cratonic mantle must have been depleted either in thick Archean MOR sequences (Herzberg and Rudnick, 2012) or in sub-arc fluxed mantle wedges (Parman et al., 2004). The redistribution of $\mathrm{Si}$ with mantle-like $\delta^{18} \mathrm{O}$ was caused by peridotite-derived melt percolation. Finally, these buoyant, depleted proto-cratonic peridotites were thickened by collisional compression (Wang et al., 2016) into the roots that have protected Earth's $>2.5$ billion year old crust.

\section{Acknowledgements}

We thank the Northwest Territories Geological Survey for funding the analytical time necessary for this project, as well as Dr. Dante Canil and an anonymous reviewer for their constructive comments, and Dr. Ambre Luguet for her editorial comments.

Editor: Ambre Luguet

\section{Additional Information}

Supplementary Information accompanies this letter at http:// www.geochemicalperspectivesletters.org/article1830. 


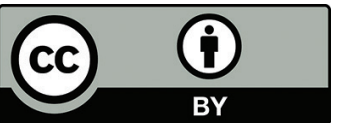

This work is distributed under the Creative Commons Attribution 4.0 License, which permits unrestricted use, distribution, and reproduction in any medium, provided the original author and source are credited. Additional information is available at http://www.geochemicalperspectivesletters.org/copyrightand-permissions.

Cite this letter as: Regier, M.E., Mišković, A., Ickert, R.B., Pearson, D.G., Stachel, T., Stern, R.A., Kopylova, M. (2018) An oxygen isotope test for the origin of Archean mantle roots. Geochem. Persp. Let. 9, 6-10.

\section{References}

BREY, G.P., SHU, Q. (2018) The birth, growth and ageing of the Kaapvaal subcratonic mantle. Mineralogy and Petrology 1-19.

CANIL, D. (2004) Mildly incompatible elements in peridotites and the origins of mantle lithosphere. Lithos 77, 375-393.

CANil, D., LeE, C.-T.A. (2009) Were deep cratonic mantle roots hydrated in Archean oceans? Geology 37, 667-670.

EILER, J.M. (2001) Oxygen Isotope Variations of Basaltic Lavas and Upper Mantle Rocks. Reviews in Mineralogy and Geochemistry 43, 319-364.

Eiler, J.M., Crawford, A., Elliott, T., Farley, K.A., Valley, J.W. STOLPER, E.M. (2000) Oxygen Isotope Geochemistry of Oceanic-Arc Lavas. Journal of Petrology 41, 229-256.

Evans, B.W. (2008) Control of the Products of Serpentinization by the $\mathrm{Fe} 2+\mathrm{Mg}-1$ Exchange Potential of Olivine and Orthopyroxene. Journal of Petrology 49, 1873-1887.

Ghiorso, M.S., Hirschmann, M.M. Riners, P.W., Kress, V.C. (2002) The pMELTS: A revision of MELTS for improved calculation of phase relations and major element partitioning related to partial melting of the mantle to $3 \mathrm{GPa}$. Geochemistry, Geophysics, Geosystems 3, 1-36.

Helmstaedt, H., Schulze, D.J. (1989) Southern African kimberlites and their mantle sample: Implications for Archean tectonics and lithosphere evolution. Kimberlites and Related Rocks 1, 358-368.

HerzberG, C., Rudnick, R. (2012) Formation of cratonic lithosphere: An integrated thermal and petrological model. Lithos 149, 4-15.

JORDAN, T.H. (1978) Composition and development of the continental tectosphere. Nature 274, 544-548.

Kelemen, P.B., Dick, H.J.B., QUiCK, J.E. (1992) Formation of harzburgite by pervasive melt/rock reaction in the upper mantle. Nature 358, 635-641.

Kelemen, P.B., Hart, S.R., Bernstein, S. (1998) Silica enrichment in the continental upper mantle via melt/rock reaction. Earth and Planetary Science Letters 164, 387-406.

LeE, C.-T.A., Luffi, P., ChIN, E.J. (2011) Building and Destroying Continental Mantle. Annual Review of Earth and Planetary Sciences 39, 59-90.

Li, Z.-X.A., LeE, C.-T.A., Peslier, A.H., Lenardic, A., Mackwell, S.J. (2008) Water contents in mantle xenoliths from the Colorado Plateau and vicinity: Implications for the mantle rheology and hydration-induced thinning of continental lithosphere. Journal of Geophysical Research 113, 1-22.

McKenzie, D., Priestley, K. (2016) Speculations on the formation of cratons and cratonic basins. Earth and Planetary Science Letters 435, 94-104.

Mitchell, A.L., Grove, T.L. (2015) Melting the hydrous, subarc mantle: the origin of primitive andesites. Contributions to Mineralogy and Petrology 170,13

Parman, S.W., Grove, T.L., DanN, J.C., DE Wit, M.J. (2004) A subduction origin for komatiites and cratonic lithospheric mantle. South African Journal of Geology 107, 107-118.

PEARSON, D.G., WitTIG, N. (2008) Formation of Archaean continental lithosphere and its diamonds: the root of the problem. Journal of the Geological Society 165, 895-914

Rosenbaum, J.M., KYSER, T.K., WALKER, D. (1994) High temperature oxygen isotope fractionation in the enstatite-olivine-BaCO3 system. Geochimica et Cosmochimica Acta 58, 2653-2660.

RUDNICK, R.L. (1994) Northern Tanzanian peridotite xenolith: a comparison with Kaapvaal peridotites and evidence for carbonatite interaction with ultra-refractory residues. Proceedings of the 5th International Kimberlite Conference, 336-353.

SCHULZE, D.J. (1986) Calcium anomalies in the mantle and a subducted metaserpentinite origin for diamonds. Nature 319, 483-485.
Stachel, T., Viljoen, K.S., Brey, G., Harris, J.W. (1998) Metasomatic processes in lherzolitic and harzburgitic domains of diamondiferous lithospheric mantle: REE in garnets from xenoliths and inclusions in diamonds. Earth and Planetary Science Letters 159, 1-12.

Valley, J.W., KinnY, P.D., Schulze, D.J., SpicuzZA, M.J. (1998) Zircon megacrysts from kimberlite: oxygen isotope variability among mantle melts. Contributions to Mineralogy and Petrology 133, 1-11.

Wang, C.-G., XU, W.-L., YAnG, D.-B., LiU, Y.-S., Pei, F.-P., LI, Q.-L., ZHOU, Q.-J. (2018) Olivine Oxygen Isotope Evidence for Intracontinental Recycling of Delaminated Continental Crust. Geochemistry, Geophysics, Geosystems 19, 1-12.

Wang, H., van Hunen, J., PeArson, D.G. (2016) Making Archean cratonic roots by lateral compression: A two-stage thickening and stabilization model. Tectonophysics, doi: 10.1016/j.tecto.2016.12.001.

Wenner, D.B., TAYlor, H.P. (1971) Temperatures of serpentinization of ultramafic rocks based on O18/O16 fractionation between coexisting serpentine and magnetite. Contributions to Mineralogy and Petrology 32, 165-185. 